\title{
Leader Self-Efficacy of Women Intercollegiate Athletic Administrators: A Look at Barriers and Developmental Antecedents
}

\author{
Moe Machida-Kosuga \\ Osaka University of Health and Sport Sciences \\ John Schaubroeck \\ Michigan State University \\ Deborah Feltz \\ Michigan State University
}

\begin{abstract}
We tested a range of facilitating and inhibiting antecedents of leader self-efficacy on a large sample of 692 women intercollegiate athletic administrators in National Collegiate Athletic Association registered institutions. Drawing from social cognitive theory (Bandura, 1997), we examined developmental challenges, peer and supervisor feedback and support, family-work conflict, and perceived gender discrimination as antecedents of leader self-efficacy. We also examined mediating roles of leader self-efficacy in career ascendance. Structural equation modeling results show that developmental challenges were indirectly related to career ascendance, as mediated through leader self-efficacy. Developmental challenges, peer and supervisor feedback, and support were positively related to leader selfefficacy, whereas family-work conflict was negatively related to leader self-efficacy. Perceived gender discrimination was not related to leader self-efficacy. These findings identify potential levers through which intercollegiate athletic institutions may support women leaders' career advancement.
\end{abstract}

Keywords: self-efficacy, administration, career development, leadership, gender

There is continuing evidence that women are under-represented in leadership positions in the U.S. intercollegiate athletics (e.g., Acosta \& Carpenter, 2014;

\footnotetext{
Machida-Kosuga is with the School of Physical Education, Osaka University of Health and Sport Sciences, Sennan-Gun, Osaka, Japan. Schaubroeck is with the Dept. of Management and the Dept. of Psychology, Michigan State University, East Lansing, Michigan. Feltz is with the Dept. of Kinesiology, Michigan State University, East Lansing, Michigan. Address author correspondence to Moe Machida at machidam@ouhs.ac.jp.
} 
Burton, 2014). Acosta and Carpenter reported that only $22.3 \%$ of intercollegiate athletic directors are women, and women hold only $36.2 \%$ of all administrative jobs in intercollegiate athletics. Yet, women participate in intercollegiate athletics in roughly the same numbers as men (Acosta \& Carpenter, 2014).

Whereas much research has provided insights into the personal and situational determinants that influence women leaders' career ascendance in various athletic professions, including intercollegiate athletic administration (e.g., Bower \& Hums, 2013; Morris, Arthur-Banning, \& McDowell, 2014; Whiteside \& Hardin, 2011; also see review by Burton, 2014), studies have not thoroughly addressed cognitive and affective processes that may impede or facilitate women's career ascendance in this field (Burton, 2014; Burton, Grappendorf, \& Henderson, 2011; Sartore \& Cunningham, 2007).

Self-efficacy has been identified and examined as a central cognitive process that influences women's careers in athletic leadership positions (e.g., Cunningham, Doherty, \& Gregg, 2007; Cunningham, Sagas, \& Ashley, 2003; Everhart \& Chelladurai, 1998; Moran-Miller \& Flores, 2011). Self-efficacy is defined as an individual's perceived capability to execute a given task (Bandura, 1997). In the field of intercollegiate athletic administration, advancement is contingent on demonstration of competencies in leading others (e.g., Burton \& Peachey, 2009; Won, Bravo, \& Lee, 2013). Ultimately, one's sense of personal agency in a leadership position may reflect a range of developmentally facilitating and inhibiting factors. Thus, leader self-efficacy may be a core determinant of whether individuals persist in pursuing the personal development and other proactive investments needed to attain higher-level administrative positions (Hannah, Avolio, Luthans, \& Harms, 2008; Ng, Ang, \& Chan, 2008). To date, however, research on self-efficacy in athletic career advancement has focused on coaches, and self-efficacy has generally been defined in terms of role or career efficacy rather specific role facets such as leader self-efficacy. Given the importance of leadership capability in athletic administration, there is need to understand the role of leader self-efficacy in women athletic administrators' career ascendance. In applying social cognitive theory (Bandura, 1997) to career advancement (e.g., Lent, Brown \& Hackett, 1994), we assessed potential barriers and facilitators of leader self-efficacy in women intercollegiate administrators. Understanding the barriers and facilitators of women athletic administrators' career ascendance should further inform and promote practices that seek to develop women leaders in athletics and beyond.

\section{Background in Research and Theory}

\section{Role of Leader Self-Efficacy in Women's Career Ascendance in Athletic Administration}

In his social cognitive theory, Bandura (1997) considers self-efficacy beliefs as central to individuals' personal agency. He defined agency as "acts done intentionally" (p. 3) and posits that human agency operates within a system of triadic reciprocal causation which involves behavior, personal factors (i.e., cognitive, affective, and biological events), and the external environment. Bandura further argues that in this system of triadic reciprocal causations, positive self-efficacy beliefs promote the learning of new skills by influencing an individual's actions, efforts, and persistence. 
In her review of career self-efficacy, Betz (2007) argued that women's restrained positions at work may be, at least in part, attributed to their low self-efficacy beliefs. Self-efficacy has been studied as one of the central constructs that are associated with career related choices and career advancement in general management (e.g., Lent et al., 1994; Tharenou, 1994; Tharenou, 2008). In athletics, Everhart and Chelladurai (1998) reported that coaching self-efficacy was related to desire to coach at various levels (i.e., high school, 2-year college, Division III, Division II, and Division I) among 191 male and female college basketball players. In the more general sport management field, Cunningham, Bruening, Sartore, Sagas, and Fink (2005) reported that vocational self-efficacy was predictive of vocational interests, which in turn was related to choice goals toward sport and leisure industry among 197 female and male undergraduate students. Further, Cunningham et al. (2007) showed that as compared with male assistant coaches $(n=35)$, female assistant coaches $(n=31)$ had lower head coaching self-efficacy, and lower interest in coaching and intentions to become a head coach in the future. Cunningham et al. (2003) also supported such gender differences in coaching self-efficacy and found that it was related to one's desire to become a head coach among 173 male and female assistant coaches. A recent study by Moran-Miller and Flores (2011) showed that coaching self-efficacy was positively related to interest in coaching among 205 female collegiate athletes. Thus, studies in athletics (i.e., mainly in coaching) suggest that especially for women, self-efficacy is critical to thriving in the athletic professions.

Although the previous work (e.g., Cunningham et al., 2003, 2005, 2007; Everhart \& Chelladurai, 1998; Moran-Miller \& Flores, 2011) provides important information regarding the possible roles of other forms of self-efficacy in women's careers in athletics, we argue that leader self-efficacy may be particularly important to the career ascendance of occupants of administrative positions in athletics. Advancement in intercollegiate athletic administration is not just about general competency in performing managerial duties. What may differentiate those who advance in their careers more quickly than others, and to persist in the fields of athletic administration, is their ability to demonstrate potential for leading others at higher levels. To do so one must develop a high level of leader self-efficacy. Based on social cognitive theory (Bandura, 1997), leader self-efficacy should provide the impetus for actions they need to persevere in developing themselves as leaders and is needed to pursue ambitious administrative career goals.

Past studies in general management have used various measures of one's career ascendance such as willingness to expatriate (Tharenou, 2008), position in the management hierarchy, salary, and number of subordinates (Tharenou, 1994) as they relate to self-efficacy beliefs. However, most studies of careers and self-efficacy in athletics have used subjective measures of career ascendance, reflecting a desire or interests in advancing one's career (i.e., head coach; e.g., Cunningham et al., 2003, 2007; Moran-Miller \& Flores, 2011), which were shown to be positively related to self-efficacy. In lieu of these subjective measures, we followed Luthans' recommendation $(1985 ; 1993)$ by operationalizing career ascendance in terms of the rate of advancement, based on the individual's position in the management hierarchy and tenure in the profession. Informed by social cognitive theory (Bandura, 1997) and its application to career ascendance, we advance the first hypothesis as follows (see also Figure 1 for our hypothesized model): 
Hypothesis 1. Leader self-efficacy is positively related to the career ascendance of women intercollegiate athletic administrators.

\section{Developmental Experiences as Facilitating Sources of Leader Self-Efficacy}

Developmental experiences suggested by leader development research (McCauley, DeRue, Yost, \& Taylor, 2013) may facilitate women's leader self-efficacy. Research on leader development suggests there are three main components of developmental experiences that facilitate leader development. First, leaders need to be challenged by difficult job assignments. Developmental challenges motivate leaders to experiment with different strategies and to master the skills needed to meet the challenges (McCauley et al. 2013). In social cognitive theory, Bandura (1997) identified mastery experiences, which are reflected in developmental challenges, as being crucial to developing self-efficacy.

Feedback is also essential to development. This may include acquiring feedback from results on one's own, from supervisors, or from peers. Feedback provides information to a developing leader about her areas of weakness, strengths, and potential means to improve (McCauley et al., 2013). Finally, to make the most of their developmental experiences, leaders need support from others. Scholars argue that the availability of support is especially critical for leaders' willingness to undertake the high risk of failure that is often critical to improvement (McCauley et al., 2013). Similar to developmental challenges, social cognitive theory provides a basis to predict that appropriate feedback and support can enhance self-efficacy. Bandura identified verbal persuasion as one of the main sources of self-efficacy. Verbal persuasion can take the form of performance feedback and positive encouragement that individuals receive from others.

Studies in general management provide support for each component of developmental experiences (i.e., challenges, feedback, and support) in individual careers (e.g., DeRue \& Wellman, 2009; Dragoni, Oh, Vankatwyk, \& Tesluk, 2011; Dragoni, Park, Soltis, \& Forte-Trammell, 2014; Ehrich, Hansford, \& Tennent, 2004). Studies in athletics also point to the roles of these elements in women's careers. For example, qualitative studies on women coaches showed that learning opportunities and education are critical in facilitating their careers (e.g., Kilty, 2006; Morris et al., 2014). Dixon and Bruening (2007) reported that personal support was particularly important to the success of women head coaches who had children. In a study of intercollegiate athletic administration, Sagas and Cunningham (2004) reported that social capital resources (including network size, intraorganizational ties, etc.) were more influential for male administrators than for their female counterparts. However, human capital resources (including training opportunities) were related to career satisfaction and promotions among both female and male athletic administrators $(n=213)$. In addition, a few studies observed relationships between developmental experiences and self-efficacy. Moran-Miller and Flores (2011) showed quality of role models was predictive of female athletes' coaching efficacy, which in turn, related to their interests in coaching. Cunningham et al. (2005) also suggested that human (i.e., education, training, and experience) and social capital (i.e., the contacts) resources were related to students' vocational self-efficacy to enter the sport and leisure careers. 
To date, however, different kinds of developmental antecedents have not been examined in conjunction. Essential elements in developmental experiences, developmental challenges, feedback, and support, are likely to be positively correlated. It is therefore essential to examine them together in multivariate analyses. Integrating social cognitive theory with knowledge concerning how leaders develop competencies led us to the following hypothesis:

Hypothesis 2. Developmental challenges (H2a), feedback (H2b), and support $(\mathrm{H} 2 \mathrm{c})$ are positively related to leader self-efficacy of women intercollegiate athletic administrators.

\section{Family-Work Conflict and Gender Discrimination as Debilitating Sources of Women's Leader Self-Efficacy}

Women who aspire to advance their careers deal with challenges that are unique to their gender. This may be especially so in athletics because it usually is associated with traditional masculine characteristics (e.g., Burton, 2014; Cunningham, 2008; Sartore \& Cunningham, 2007). First, family barriers (e.g., family's disapproval, partner's career, having children) are seen to strongly affect the career decisions of women (e.g., Loder, 2005; Tharenou, 2008). These constraints are reflected in higher family-work conflict levels reported by women than by men (e.g., Ernst-Kossek, \& Ozeki, 1998; Hoobler, Wayne, \& Lemmon, 2009). Netemeyer, Boles, and McMurrian (1996) defined family-work conflict as "a form of inter-role conflict in which the general demands of, time devoted to, and strain created by the family interfere with performing work-related responsibilities" (p. 401). Studies in general management have found that family-work conflict was negatively related to job satisfaction (Ford, Heinen, \& Langkamer, 2007), family satisfaction, life satisfaction, and organizational commitment (Carlson, Kacmar, \& Williams, 2000), and positively related to turnover intentions, job tension, role conflict, role ambiguity (Netemeyer et al., 1996), and guilt (Livingston \& Judge, 2008). In athletics, long working hours and associated family-work conflicts have been identified as barriers for women (e.g., Bruening \& Dixon, 2007; Sagas \& Cunningham, 2005). For example, with 115 assistant coaches of women's teams, Sagas and Cunningham showed that a dimension of family-work conflict (i.e., a strain-based family interference with work) was negatively related to female assistant coaches' job satisfaction, but none of the dimensions of family-work conflict was related to male assistant coaches' job satisfaction. By impeding their ability to provide full attention and energy to developing their skills as leaders, family-work conflict may pose a significant barrier to women's career advancement in intercollegiate athletic administration.

Second, particularly in male-dominated fields such as athletics, gender stereotyping and overt gender discrimination may pose another obstacle to women's leadership development (e.g., Sartore \& Cunningham, 2007; Shaw \& Hoeber, 2003). Scholars argue that sport is "a gendered space" (Burton, 2014). Gender discrimination and gender stereotypes have been identified by numerous studies as barriers for women's careers in athletics (e.g., Burton, et al., 2009; Kilty, 2006; Whisenant, 2008). For example, Burton, Grappendorf, and Henderson (2011) asked 276 athletic administrators to evaluate a hypothetical male or female candidate for positions in athletic administrations including an athletic director position. The 
results showed that though male and female candidates were evaluated similarly for their potential to succeed in all positions, athletic administrators perceived that a female candidate would have less chance to be offered an athletic director position. Past research in athletics suggest that gender discrimination may be deeply embedded in athletics (Burton, 2014). Those women who report experiences of gender discrimination may view the prospect of future gender discrimination as an impediment to their future career progress, and this may discourage their ambition to advance their career.

When faced with difficulties such as family-work conflict and gender discrimination, women are less likely to perceive that they have the opportunity to develop their competencies sufficiently to advance their careers. Women who have faced high levels of obstacles such as family-work conflict and gender discrimination have experienced anxiety, frustration, and other adverse affective states (Livingston \& Judge, 2008). Such physiological and affective states are among the main determinants of self-efficacy levels (Bandura, 1997). Scholars argue that the gendered culture of athletics could limit women's assessment about their capabilities to succeed in their careers (Sartore \& Cunningham, 2007). Research in other achievement domains, such as entrepreneurship, demonstrates this potential of gender-specific career barriers to undermine women's self-efficacy (Gupta, Turban, \& Bhawe, 2008; Netemeyer et al., 1996). In athletics, MoranMiller and Flores (2011) reported a significant negative relationship between anticipated working hours and coaching self-efficacy, but the relationship between perceived gender discrimination and coaching self-efficacy among female collegiate athletes was not significant. On the other hand, Cunningham et al. (2005) reported that perceptions of barrier discrimination (based on any demographics including gender) were negatively related to undergraduate students' vocational self-efficacy associated with sport and leisure careers.

Thus, in general, there is limited research on how difficulties such as familywork conflict and perception of gender discrimination influence one's career related self-efficacy in athletics even though such relationships can be predicted from social cognitive theory (Bandura, 1997). Though no study directly investigated the relationship between family-work conflict and self-efficacy in athletic careers, a past study suggests that expected working hours potentially lowers self-efficacy (Moran-Miller \& Flores, 2011). Studies report mixed results regarding the influences of gender discrimination on self-efficacy (Cunningham et al., 2005; Moran-Miller $\&$ Flores, 2011) and these equivocal findings regarding discrimination may be due to the sample characteristics (i.e., they were not current leaders). The relationships between family-work conflict and perception of gender discrimination and women athletic administrators' leader self-efficacy have not been fully addressed in the past studies. In the current study, we predict that:

Hypothesis 3. Family-work conflict (H3a) and perceived gender discrimination (H3b) are negatively related to leader self-efficacy of women intercollegiate administrators.

\section{Mediating Influences of Leader Self-Efficacy}

Few studies investigated a mechanism through which any of the aforementioned antecedents influence career progress. We suggest that a sense of personal agency 
(i.e., self-efficacy) is a key mechanism through which developmental advantages (i.e., developmental challenges, feedback, and support) and disadvantages (i.e., family-work conflict and gender discrimination) influence women's ascendance to higher levels of intercollegiate athletic administration. Wang, Lawler, and Shi (2010) found that self-efficacy mediates the relationship between familywork conflict and work satisfaction among bankers in Asia. Ng et al. (2008) reported that leader self-efficacy mediated the relationship between personality dispositions and leader effectiveness among military recruits. As we noted above, studies have examined the different developmental aspects of jobs as perceived by their incumbents (i.e., developmental challenges, feedback, support) separately, despite their plausibly high correlations between these factors. In addition, perceptions of family-work conflict and gender discrimination may tend to coincide to an extent. Each may be negatively related to perceived developmental characteristics. The factors may therefore not explain entirely unique variances in leader self-efficacy, and examining these factors together in the same analyses might accordingly result in some factors accounting for the influence of other factors. However, we have no theoretical basis to propose any of these factors as having primacy over the others. We therefore examine the influences of the factors through leader self-efficacy as an exploratory research question.

Research Question 1. Are developmental challenges, feedback, support, family-work conflict, and perceived gender discrimination indirectly related to career ascendance through leader self-efficacy?

\section{Method}

\section{Participants}

Participants were 692 women intercollegiate athletic administrators in the institutions registered by the National Collegiate Athletic Association (NCAA) in the United States. The mean age of participants was 37.80 years $(S D=10.78)$ and mean years in athletic administration were 8.55 years $(S D=6.94)$. On average, participants had worked in their current positions for 5.19 years $(S D=5.36)$. Among participants who indicated their race $(n=553)$, more than $90 \%$ of participants identified themselves as Caucasian $(n=499,90.24 \%)$, with small percentages identifying other ethnic categories including African American $(n=30 ; 5.42 \%)$, Hispanic $(n=8 ; 1.44 \%)$, Asian $(n=6 ; 1.11 \%)$, Pacific Islander $(n=4 ; 0.72 \%)$, and Native American ( $n=2 ; 0.36 \%)$, and "others" and "interracial" totaled $1.08 \%$. Participants' positions and NCAA divisional categorization are presented in Table 1. Twenty-one participants indicated they also held head or assistant coach positions of their university teams.

\section{Procedures}

The survey was administered online and we obtained informed consents from the participants before they began the survey. Aside from the demographic questions that appeared at the end of the survey, we randomized the order of the measures on 
Table 1 Number of Participants by Titles and Divisions

\begin{tabular}{lcccc}
\hline & \multicolumn{3}{c}{ Division } & \\
\cline { 2 - 4 } Position & Division I & Division II & Division III & Total \\
\hline Director of athletics & 92 & 5 & 117 & 104 \\
Associate athletic director & 107 & 18 & 36 & 165 \\
Assistant athletic director & 62 & 34 & 37 & 134 \\
$\begin{array}{l}\text { Director/coordinator/manager of a } \\
\text { division }\end{array}$ & 83 & 20 & 18 & 122 \\
$\begin{array}{lllll}\text { Assistant director/coordinator/man- } \\
\text { ager of a division }\end{array}$ & 4 & 2 & 22 & 28 \\
Total & 348 & 79 & 117 & 553 \\
\hline
\end{tabular}

Note. Divisions include Academics, Compliance, etc. and include Senior Women Administrator. If participants hold two or more positions, the higher administrative positions are indicated in the table.

the survey and the order of items within each measure. We asked athletic directors in all NCAA institutions to disseminate a link to their women athletic administrators and we emailed the survey link to women athletic administrators directly. Their e-mail addresses were obtained from the institutions' official athletic websites. We also asked participants to forward the posting about the study to their women counterparts in intercollegiate athletic administration. In addition, we asked professional organizations for intercollegiate athletic administrators to disseminate the information about the study to their members. Using the number of women intercollegiate athletic administrators we contacted directly as a base $(N=2,308)$, our estimate of response rate is $29.9 \%$. The survey was conducted anonymously and the university institutional review board approved our study procedure.

\section{Measures}

Career Ascendance. We operationalized a career ascendance by adapting a formula for measuring manager success used by Luthans, Rosenkrantz, and Hennessey (1985). Their manager success index (MSI) is calculated as follows:

$$
M S I=\frac{5(6-\text { level })}{\text { Organization Tenure }} \times 100
$$

Level represents one's position in the organization, with 5 being the lowest and 1 being the highest. The value of 5 represents "a constant progression factor - the time in grade per number of career moves available if one were to spend his work life in an eight-level organization" (Hall, 1976, p. 7). Thus, this index assumes that as individuals attain higher-level positions, they are more successful, particularly if they have less tenure in the organization (i.e., because they have less time to advance in the organization). We used the following formula to assess career ascendance in athletic administration;

$$
\text { Career Ascendance }=\frac{5(6-\text { level })}{\text { Years in Athletic Category }} \times 100
$$


Instead of organization tenure, we used years of experiences in the field of athletic administration in the denominator because it is a common practice for the athletic administrators to transfer between institutions. Organization tenure might not be an accurate representation of time available for one's promotion to a higher level. In addition, some athletic administrators move from coaching positions to administrative positions within the same institution. As a result, organization tenure values can include time an individual has served as a coach, which is a very different type of position within athletics. Organizational Level 1 was assigned to athletic directors, Level 2 was assigned to associate athletic directors, Level 3 was assigned to assistant athletic directors, Level 4 was assigned to directors/managers/coordinators of a specific division (e.g., Academics, Finance) in athletic department, and Level 5 was assigned to associate and assistant directors/managers/coordinators of a specific division in athletic department.

Promotions do not occur on a year-by-year basis in intercollegiate athletic administration. Differences of one to three years of tenure in an organization may not be pertinent to measuring ascendance. Instead of utilizing the raw number of years in athletic administration, we categorized the athletic administration tenures in bands using the demographic information of the women intercollegiate athletic administrators who participated in the study. Because we used five categories in athletic administration career based on Hall (1976), we also categorized number of years in athletic administration into five categories. In Sagas and Cunningham's (2004) study, the average numbers of promotions reported by athletic administrators ranged between 2.37 and 3.45 (for high and low social and human capital groups) with an average tenure of 11.67 years. Thus, it seems that administrators may take approximately $3.5-5.0$ years to be promoted. Among our study participants, median and mean years of experiences in athletic administration were 6.25 years and 8.54 years $(S D=6.93,95 \% \mathrm{Cl}: 7.95-9.14)$ respectively. With their mean years serving as the center point, we placed participants into categories delineated by the range of rates of career progression reported by Sagas and Cunningham (2004). Thus, athletic administration tenures were categorized into the following five categories: 1 (0-3.99 years: $n=146,27.7 \%), 2$ (4-6.99 years: $n=123,23.3 \%), 3(7-9.99$ years: $n=75,14.2 \%), 4(10-14.99$ years: $n=90,17.1 \%)$, and 5 (15 years and up: $n=93,17.6 \%$ ).

We also adjusted for the differences between the three NCAA Divisions. Division I institutions generally have bigger facilities, more teams and athletes, and greater financial and personnel resources. Division III institutions are considered to have the least resources. Thus, career ascendance is not only reflected in one's rise in an institutional hierarchy; it is also reflected in the Division level of one's current institution. Using the information about the percentage of women intercollegiate administrators in Division I, II, and III institutions around the time of data collection (30\%, 37\%, 45\% respectively, Acosta \& Carpenter, 2012), we calculated the ratio of women holding positions between Divisions (i.e., Division III vs. Division II, $45 / 37=1.22$; Division III vs. Division I, $45 / 30=1.5)$. Then, based on these ratios, we multiplied the denominator in the equation by a factor of 1.5 for Division I, whereas for Division II institutions the factor was 1.25.

Developmental Challenges. We adapted the Developmental Challenge Profile (McCauley, Ohlott, \& Ruderman, 1999) to measure developmental challenges 
experienced at work. Before the data collection, we emailed 10 experienced women athletic administrators (four were also professors and six had Ph.D. degrees) who were former and current athletic directors/senior associate athletic directors. They were recruited to evaluate the content validity and relevance of each item in the profile to the job demands of athletic administration, thus asked to serve as the subject matter experts. Four of the 10 responded to our invitation to complete the online survey. They used a scale of 1 (not relevant) to 5 (extremely relevant) to evaluate each item on the survey. Modifications were made to several items to fit them based on their feedback. For example, the item, "The customer base you work with is extremely varied" was modified to "The groups (e.g., conferences, institutions) you work with outside the department are extremely varied." One subscale, work across cultures, which describes the managers' responsibility to work with people from different cultures and other countries (e.g., "you conduct business with people from different countries"), was not included in further data collection. We omitted this scale due to consistent feedback from the subject matter experts that these items were not relevant to the job demands of athletic administration. Thus, the final instrument used in measuring developmental challenges consisted of five subscales (45 items): (a) unfamiliar responsibilities (five items, e.g., "You lack experience important to carrying out some aspect of your job"), (b) creating change (15 items, e.g., "You have to carry out a major reorganization as a result of a merger, acquisition, downsizing, or rapid growth"), (c) managing at high levels of responsibility, (10 items, e.g., "You are responsible for decisive action in a highly charged environment"), (d) managing boundaries (10 items, e.g., "You manage relationships with government officials or regulatory agencies"), and (e) dealing with diversity, (5 items, e.g., "You have to get people from different racial, religious, cultural, or ethnic backgrounds to work together"). Participants rated the extent to which each item described their current job on a scale of 1 (not at all descriptive) to 5 (extremely descriptive).

Feedback. Participants reported quality of feedback they received from supervisors and peers using an instrument reported by Newstrom, Monczka, and Reif (1974). Participants rated nine semantic differential items in which each pair of descriptors served as the labels for the poles of a 7-point (1-7) scale. The anchors of these items are as follows: unfair-fair, weak-strong, good-bad, soft-hard, valuable-worthless, pleasant-unpleasant, vague-clear, supportive-unsupportive, and frequent-infrequent. For example, for the vague-clear item, "completely vague" was rated as 1 and "completely clear" as 7 .

Support. Perceived support was measured using two separate adaptations of the 4-item work developed by Haynes, Wall, and Bolden (1999). One subscale referred to support from "colleagues," while the other referred to support from "supervisors." Participants indicated the extent to which their supervisors and peers provided them with help or support (e.g., "To what extent can you count on your colleagues/supervisors to listen to you when you need to talk about problems at work?") on a scale of 1 (not at all) to 5 (completely).

Family-Work Conflict. Time-based family interference with work (three items, e.g., "The time I spend on family responsibilities often interfere with my work responsibilities.") and strain-based family interference with work (three items, e.g., "Due to stress at home, I am often preoccupied with family matters at work.") 
subscales from the Work-Family Conflict Scale (Carlson et al., 2000) were used to measure family-work conflict. The measures were assessed on a scale of 1 (strongly disagree) to 5 (strongly agree).

Perceived Gender Discrimination. We used a 4-item scale (Foley, Hang-Yue, \& Wong, 2005; Sanchez \& Brock, 1996) to assess participants' perceptions of gender discrimination at work. Examples of items included, "At work, many people have sex stereotypes and treat me as if they were true." Participants indicated their agreements for each item based on a five-point scale ( $1=$ strongly disagree, $5=$ strongly agree).

Leader Self-efficacy. We assessed leader self-efficacy with the 22-item Generalized Leadership Self-Efficacy Measure (Hannah, Avolio, Chan, \& Walumbwa, 2012). Participants indicated their levels of confidence in their ability to accomplish each task or activity as leaders in their organization on a scale of 0 (not at all confident) to 10 (totally confident). An example item is "Inspire followers to go beyond their self-interests for the greater good."

\section{Data Analyses}

We used structural equation modeling (SEM) with Mplus Version 7.1 (Muthén \& Muthén, 2012) to test the hypotheses represented in Figure 1. Missing data were

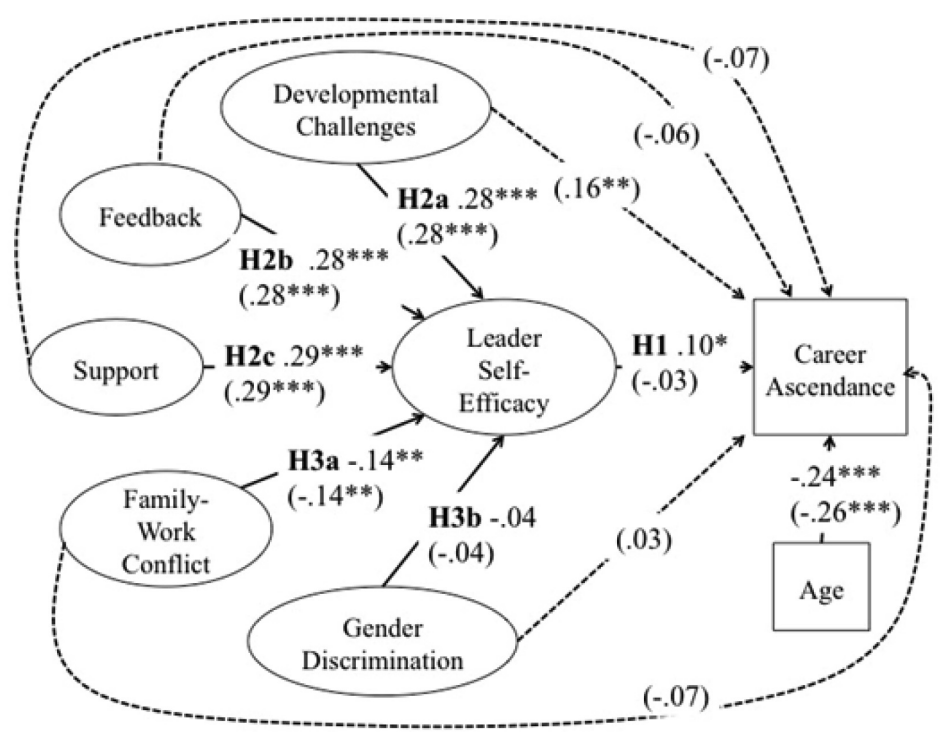

Figure 1 - Hypothesized model of women leaders' career ascendance. Note: All correlations among exogenous variables and 26 covariances between specific error terms were estimated. These parameters, as well as the loadings of specific facets onto latent variables and specific error variances, are not shown. Model 2 path coefficients are shown in parentheses beneath Model 1 coefficients. Paths added in Model 2 are represented by dashed arrows. $\rightarrow \rightarrow * * * p<.001, * * p<.01 *, p<.05$. 
handled with full information maximum likelihood estimation. To reduce the model complexity and achieve the parsimony, we used parceling (i.e., creating composites) to indicate latent constructs that have larger numbers of items (i.e., leader selfefficacy, feedback, developmental challenges) (Landis, Beal, \& Tesluk, 2000). We reduced the 22-item leader self-efficacy scale to four parcels (i.e., randomly reduced it to two 5-item parcels and two 6-item parcels). For the feedback scale, which consisted of nine items each for both peer and supervisor feedback (i.e., 18 items total), we created three 3-item parcels each for both peer and supervisor feedback by randomly combining the items; thus we reduced it to 6 parcels to indicate a latent construct of feedback. For the 45-item developmental challenge scale, five parcels were created to represent the five theoretical higher-order dimensions identified by McCauley et al. (1999) (i.e., unfamiliar responsibilities, creating change, managing at high levels of responsibility, managing boundaries, and dealing with diversity).

We first tested a measurement model, with each indicator specified to load on its corresponding scale only. Modification indices indicated that a number of specific error variances corresponding to the same theoretical constructs covaried significantly. We included 26 of these parameters in the measurement model. None of the factor loadings changed more than a negligible amount after estimating these parameters. The measurement model fit the data well, $\chi^{2}(N=692, d f=454)$ $=1038.86, \mathrm{CFI}=.96, \mathrm{TLI}=.95, \mathrm{RMSEA}=.043$. Factor loadings ranged from .38 to .93 , with one exception. The exception was the "unfamiliar responsibility" indicator to "developmental challenges," for which the standardized loading coefficient was.12 $(p=.051)$. Eliminating this indicator did not significantly change the other factor loadings or the overall fit of the model. Bearing this in mind and considering the theoretical importance of this variable (McCauley et al., 1999), we retained this parcel in further analyses.

\section{Results}

\section{Tests of Hypotheses}

Descriptive statistics including alpha reliabilities and correlations for the study variables are presented in Table 2 . There was a significant negative correlation between career ascendance and age. This was not surprising considering that number of years experience in athletic administration was included in the denominator of the equation to calculate career ascendance, and this tends to correlate with age. We conducted supplementary analyses that excluded antecedent variables one at a time and examined the corresponding change in the beta coefficient for the leader selfefficacy-career ascendance relationship. These analyses identified age as the primary suppressor variable. Age fit the pattern expected for a suppressor variable in that it was negatively correlated with career ascendance and positively correlated with leader self-efficacy. We therefore included age as a control variable in the model.

We first tested the hypothesized model in which the antecedent variables were indirectly related to career ascendance through leader self-efficacy (see Model 1 in Figure 1). Career ascendance was also regressed on age. This full mediation model fit the data well, $\chi^{2}(N=484, d f=519)=1046.69, \mathrm{CFI}=.95, \mathrm{TLI}=.94$, RMSEA $=.046$. The relationship between leader self-efficacy and career ascendance was weak, but positive and significant $(\beta=.10, p=.04$, Hypothesis 1$)$. Developmental 


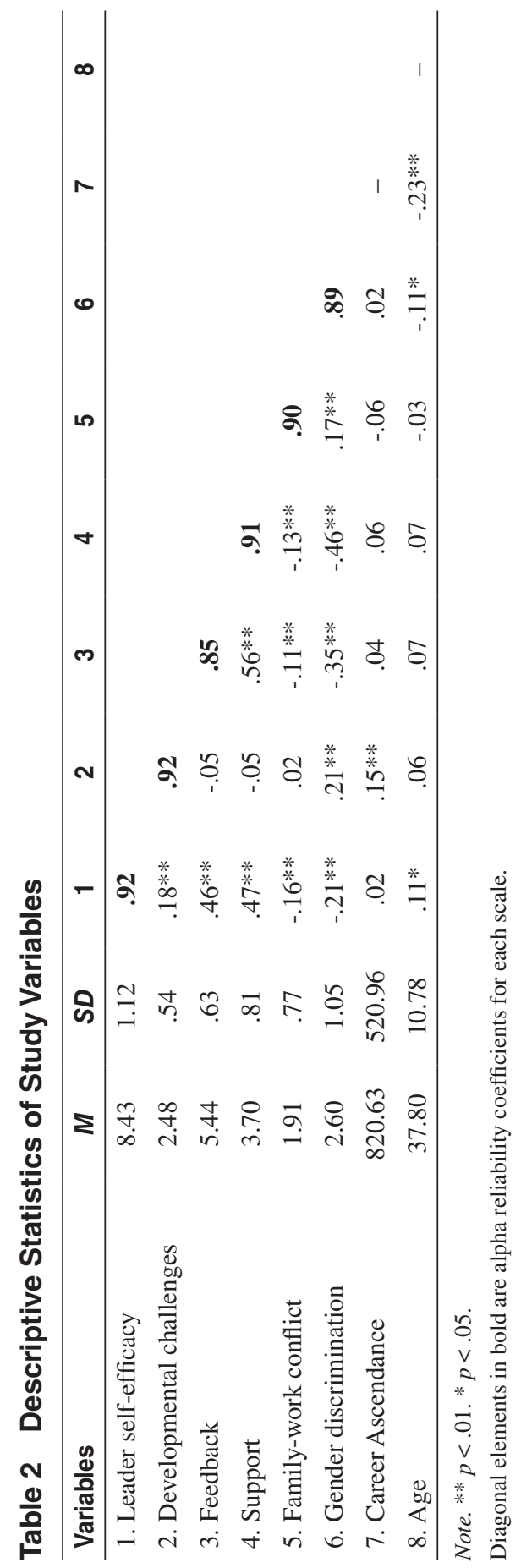

JIS Vol. 9, No. 2, 2016 
challenges, feedback, and support were positively and moderately related to leader self-efficacy $(\beta=.28, \beta=.28$, and $\beta=.29$, respectively, $p<.001)$. These findings support Hypotheses $2 \mathrm{a}, 2 \mathrm{~b}$, and $2 \mathrm{c}$. However, Hypothesis 3 was only partially supported. Although the magnitude of coefficient was small, family-work conflict was negatively related to leader self-efficacy $(\mathrm{H} 3 \mathrm{a} ; \beta=-.14, p=.001)$. The relationship between gender discrimination and leader self-efficacy $(\mathrm{H} 3 \mathrm{~b})$, however, was not significant.

Next, we examined whether the developmental challenges, feedback, support, family-work conflict, and gender discrimination indirectly related to career ascendance through leader self-efficacy (Research Question 1). Sobel tests showed that the indirect effect of developmental challenge on career ascendance through leader self-efficacy was significant (see Table 3). However, the other indirect effects were not significant. The bootstrap results concerning the indirect effects were consistent with the Sobel tests results. This provides partial support for indirect effects as per Research Question 1.

\section{Table 3 Sobel Tests and Bootstrap Results for Indirect Effects}

\begin{tabular}{|c|c|c|c|c|c|c|}
\hline \multirow[b]{2}{*}{ Indirect Effects } & \multicolumn{4}{|c|}{ Sobel Tests Results } & \multicolumn{2}{|c|}{$\begin{array}{c}\text { Bootstrap } \\
\text { Confidence } \\
\text { Interval }\end{array}$} \\
\hline & Value & SE & $\mathbf{z}$ & $p$ & $\begin{array}{l}95 \% \\
\text { CI LL }\end{array}$ & $\begin{array}{l}95 \% \\
\text { CI UL }\end{array}$ \\
\hline \multicolumn{7}{|c|}{$\begin{array}{l}\text { Challenges } \rightarrow \text { Leader Self-Efficacy } \rightarrow \\
\text { Career Ascendance }\end{array}$} \\
\hline Model 1 & .027 & .014 & 1.968 & .049 & .001 & .052 \\
\hline Model 2 & -.008 & .018 & -.475 & .635 & -.042 & .025 \\
\hline \multicolumn{7}{|c|}{$\begin{array}{l}\text { Feedback } \rightarrow \text { Leader Self-Efficacy } \rightarrow \\
\text { Career Ascendance }\end{array}$} \\
\hline Model 1 & .027 & .015 & 1.830 & .067 & -.003 & .058 \\
\hline Model 2 & -.009 & .018 & -.473 & .637 & -.047 & .030 \\
\hline \multicolumn{7}{|c|}{$\begin{array}{l}\text { Support } \rightarrow \text { Leader Self-Efficacy } \rightarrow \\
\text { Career Ascendance }\end{array}$} \\
\hline Model 1 & .028 & .015 & 1.839 & .066 & .000 & .056 \\
\hline Model 2 & -.009 & .018 & -.476 & .634 & -.045 & .027 \\
\hline \multicolumn{7}{|c|}{$\begin{array}{l}\text { Family-Work Conflict } \rightarrow \text { Leader } \\
\text { Self-Efficacy } \rightarrow \text { Career Ascendance }\end{array}$} \\
\hline Model 1 & -.0013 & .005 & -1.760 & .078 & -.028 & .001 \\
\hline Model 2 & .004 & .009 & .472 & .637 & -.014 & .022 \\
\hline \multicolumn{7}{|c|}{$\begin{array}{l}\text { Gender Discrimination } \rightarrow \text { Leader } \\
\text { Self-Efficacy } \rightarrow \text { Career Ascendance }\end{array}$} \\
\hline Model 1 & -.004 & .005 & -.743 & .457 & -.016 & .008 \\
\hline Model 2 & .001 & .003 & .412 & .680 & -.008 & .010 \\
\hline
\end{tabular}


The next model incorporated direct influences of each antecedent variable on career ascendance (see Model 2 in Figure 1). This partial mediation model also fit the data well, $\chi^{2}(N=484, d f=514)=1034.10, \mathrm{CFI}=.95, \mathrm{TLI}=.94$, RMSEA $=$ .046 . However, the change in model fit relative to Model 1 was small. Adding these direct paths to career ascendance significantly reduced the chi-square $\left(\Delta \chi^{2}(5)=\right.$ $12.59, p<.05)$, but had no impact on the other fit statistics. The lower parsimony of Model 2 and the number of nonsignificant paths in that model led us to conclude that Model 1 was better supported than Model 2.

\section{Discussion}

In the current study, we tested a range of core theoretical antecedents as antecedents of leader self-efficacy and career ascendance of a large sample of women administrators in the U.S. intercollegiate athletics. We found that developmental challenges, feedback, and support each independently, moderately and positively related to leader self-efficacy. Family-work conflict was negatively related to leader self-efficacy, though the magnitude of relationship was relatively small. In addition, there was a significant but small link between leader self-efficacy and an objective index of career ascendance, providing a partial explanation for how developmental antecedents and family-work conflict influence women intercollegiate athletic administrator's career progress.

\section{Theoretical and Research Implications}

Scholars have argued that self-efficacy is critical in leader effectiveness and development (e.g., Hannah et al., 2008; Lent et al., 1994) and careers in athletics (e.g., Cunningham et al., 2005, 2007; Everhart \& Chelladurai, 1998; Moran-Miller \& Flores, 2011). In establishing a positive relationship between leader self-efficacy and career ascendance, our study may encourage further research into ways that athletic organizations can better support women's career advancement. Our findings indicate that the three core elements of leader developmental experiences identified in leader development research (McCauley et al., 2013), developmental challenges, feedback, and support, may also contribute favorably to enhancing leader selfefficacy beliefs of women intercollegiate athletic administrators. The results from our study also add to the findings from past studies, which imply the importance of these elements in women's careers in athletics (e.g., Dixon \& Bruening, 2007; Kilty, 2006; Morris et al., 2014; Sagas \& Cunningham, 2004) and their vocational self-efficacy (Cunningham et al., 2005; Moran-Miller \& Flores, 2011). The past studies in the area have mainly examined effects of one or two of the elements we tested in the current study. The present study extends the findings in the area by testing these antecedents simultaneously, while also examining the influences of core developmental components of work (i.e., developmental challenges, feedback, support). Success in athletic administration careers demands strong leadership skills, and confidence in such skills may become a core determinant of whether individuals persist in pursuing the personal development to achieve higher administrative positions (Hannah et al., 2008; Ng et al., 2008). The connection between leader developmental experiences and leader self-efficacy suggests a significant pathway through which leader developmental experiences may influence career ascendance of women in intercollegiate athletic administration. 
The finding regarding developmental challenges is consistent with Bandura's (1997) argument in social cognitive theory that self-efficacy beliefs are a cognitive mechanism that mediates self-appraisal information (i.e., sources) and individuals' subsequent cognitive, motivational, affective, and selective processes (i.e., choices) in ways that increase effort and perseverance and ultimately task success, and our study also confirmed that it extends them to career outcomes which depend considerably on effort and perseverance. As reviewed by Bandura (1997), the strongest antecedent of self-efficacy information is mastery experience. The significant indirect effect of developmental challenges on ascendance through leader self-efficacy may be due to the strong effects of mastery experiences derived from these developmental challenges.

Feedback provides a yardstick through which women in intercollegiate athletic administration can learn whether they are on course in their developmental progress or need to modify their behavior. Support not only provides a needed resource; it also provides reassurance that enables junior leaders to persevere through the many failures necessary to develop rapidly toward more senior positions (McCauley et al., 2013). Feedback and support exhibited relationships with leader self-efficacy that were of similar magnitude to that of developmental challenge, but owing to slightly larger standard errors, their indirect effects were only marginally significant $(p<.10$, see Table 3$)$. The results from the current study may reflect not only how these variables better enable mastery experiences; they may also reflect the success of others in persuading individuals that they should have confidence in their leadership ability. These findings are in line with social cognitive theory (Bandura, 1997), which posits that there are multiple information sources of self-efficacy beliefs and that each has its unique effect on one's self-efficacy beliefs.

Our results also implicate the roles of difficulties relating to family-work conflict and gender discrimination in career ascendance of women in intercollegiate athletic administration. Past research suggests that family duty and family-work conflict could be a hindrance to career development of women in athletics (e.g., Bruening \& Dixon, 2007; Dixon \& Sagas, 2007; Sagas \& Cunningham, 2005). Our results suggest that many women currently working in intercollegiate athletic administration may not be able to maintain a high level of self-efficacy about their leadership when their home lives interfere with their work. Careers in athletic administration are demanding and may put significant strain on women; familywork conflict could contribute to women experiencing negative physiological and affective reactions that impede their confidence in furthering their careers. The present findings indicate that it could play a significant role in women's career ascendance in intercollegiate athletic administration.

\section{Practical Implications}

The findings suggest potential ways intercollegiate athletic departments may enhance women administrators' leader self-efficacy in their development. Developmentally challenging job assignments, continual high quality feedback, and support from peers and supervisors appear to facilitate their leader self-efficacy. In addition, because past studies in management indicate that women are normally provided with fewer developmental opportunities than men (Betz, 2007; van Vianen \& Keizer, 1996), supervisors and more senior administrators should make 
conscious efforts to provide their women administrators with such experiences, as these may increase their confidence as leaders, and in turn, aid their retention and advancement in the field.

Furthermore, as also indicated in the current study and past studies (e.g., Bruening \& Dixon, 2007; Sagas \& Cunningham 2005), family-work conflict can deter women from pursuing higher leadership positions in intercollegiate athletics. Though life-work balance has been called an important issue to be solved in the U.S. intercollegiate athletics (NCAA; Landice, 2009), our results suggest that it will continue to be critical for athletic departments to find and adopt best practices that minimize family-work conflict. For example, employees' sense of control regarding timing, duration, and location of their work is shown to be related to reduction in family-work conflict (see meta-analysis by Byron, 2005). Studies report that the initiatives implemented in organizations for better schedule control of employees demonstrate effectiveness (e.g., the Results Only Work Environment; ROWE; Kelly, Moen, \& Tranby, 2011). Byron (2005) also indicated that women may benefit more from these flexible work schedule environment in decreasing family-related conflicts. NCAA (Landice, 2009) also has made recommendations regarding the flexible work schedules for employees in athletic departments. Such organizational initiatives could decrease family-work conflicts for their women athletic administrators.

\section{Limitations and Future Directions}

Besides the index of career ascendance, our study was otherwise reliant on data from self-reports. The common method of response may have influenced the strengths of relationships we observed (Podsakoff, MacKenzie, \& Podsakoff, 2003). Future investigations will ideally use alternative and multiple sources of data. Our career ascendance index was adopted from general management literature (Luthans, et al., 1985). A career ascendance index that is more pertinent to the field of athletic administration using some of the other measures of career ascendance (e.g., number of promotions, increase in salary) may be necessary. Supervisors and peers' evaluations of their competencies may also be used as a measurement of career ascendance of women leaders in athletics for the future studies.

While we observed little relationship between respondents' assessments of their own exposure to gender discrimination and their leader self-efficacy or career ascendance, it is important to note that this study focused on women who are already working in the intercollegiate athletic administration. Thus, the censoring of the data may have contributed to this result, leaving a filtered sample that may be uniquely resilient to permitting gender discrimination from sapping their confidence or motivation to progress in their careers (see Ryan, Sacco, McFarland, \& Kriska, 2000). It is also possible that gender discrimination reduces women's opportunities to enter the field of intercollegiate athletic administration. When women perceive their gender is a hindrance to advancing in any particular career field, they are likely to choose an alternative field for which they have higher outcome expectations. Thus, it would be useful for prospective studies to follow women who are preparing to enter into leadership careers, such as college interns and possibly college athletes and coaches, and track their changing experiences and perceptions during their attempts to gain leadership positions and enter into 
the early phases of a leadership career. Such research could potentially identify their key experiences, perhaps identifying specific triggers that deter women from pursuing leadership careers. Ours was not a prospective study of leadership, and therefore we could not examine traits and experiences that may have led some women leaders to leave leadership careers in intercollegiate athletic administration. For example, whereas we observed a nonsignificant relationship between perceived gender discrimination and leader self-efficacy, studies with less censored data might exhibit stronger relationships.

Also, we focused our attention on testing antecedents of leader self-efficacy among a large sample of women intercollegiate administrators, and it was not our aim of the study to compare between women and men. However, future research could investigate whether the findings from the current study apply equally to men counterparts. It seems likely that the roles of the factors tested in our model differ between women and men. For example, though it has not been shown in this particular context of athletic administration, research from other athletic contexts (e.g., coaching, athletic performance) indicate that women tend to be less efficacious than men (Cunningham et al., 2003, 2007) or there is no gender difference (Everhart \& Chelladurai, 1998). In addition, Sagas and Cunningham (2004) reported possible differential returns from social capital resources (i.e., social networks) between women and men intercollegiate athletic administrators. Other research indicates that family-work conflict or family-issue presents a greater barrier to women than men (e.g., Ernst Kossek \& Ozeki, 1998; Hoobler et al., 2009) or to men than women (Inda, Rodríguez, \& Peña, 2013). While these particular gender differences already seem clear, it would be useful to test our model using a mixed-gender sample to determine not only gender differences in the magnitudes of factors, but also if the developmental antecedents and barriers exhibit differential relationships with leader self-efficacy and career ascendance.

\section{Conclusions}

Our study identifies key points of leverage to assist women in intercollegiate athletic administration who wish to advance to higher-level leadership positions. Ensuring a larger representation of women in the higher echelons of this field is contingent not only on reducing barriers such as those presented by competing family demands, but also on facilitating their development as effective leaders who desire to commit themselves to a long leadership career.

\section{References}

Acosta, R.B., \& Carpenter, L.J. (2012). Women in intercollegiate sports: A longitudinal, national study thirty-five year update. Retrieved from http://webpages.charter.net/ womeninsport

Acosta, R. B., \& Carpenter, L. J. (2014). Women in intercollegiate sports: A longitudinal, national study, thirty-seven year update. Retrieved from http://www.acostacarpenter.org/

Bandura, A. (1997). Self-efficacy: The exercise of control. New York: W. H. Freeman.

Betz, N.E. (2007). Career self-efficacy: Exemplary recent research and emerging directions. Journal of Career Assessment, 15, 403-422. doi:10.1177/1069072707305759 
Bower, G.G., \& Hums, M.A. (2013). The impact of Title X on career opportunities in intercollegiate athletic administration. Journal of Intercollegiate Sport, 6, 213-230. doi:10.1123/jis.6.2.213

Bruening, J.E., \& Dixon, M.A. (2007). Work-family conflict in coaching II: Managing role conflict. Journal of Sport Management, 21, 471-496. doi:10.1123/jsm.21.4.471

Burton, L.J. (2014). Underrepresentation of women in sport leadership: A review of research. Sport Management Review, 18, 155-165. doi:10.1016/j.smr.2014.02.004

Burton, L.J., Barr, C.A., Fink, J.s., \& Bruening, J.E. (2009). "Think athletic director, think masculine?": Examination of the gender typing of managerial subroles within athletic administration positions. Sex Roles, 61, 416-426. doi:10.1007/s11199-009-9632-6

Burton, L.J., Grappendorf, H., \& Henderson, A. (2011). Perceptions of gender in athletic administration: Utilizing role congruity to examine (potential) prejudice against women. Journal of Sport Management, 25, 36-45. doi:10.1123/jsm.25.1.36

Burton, L.J., \& Peachey, J.W. (2009). Transactional or transformational? Leadership preferences of Division III athletic administrators. Journal of Intercollegiate Sport, 2, 245-259. doi:10.1123/jis.2.2.245

Byron, K. (2005). A meta-analytic review of work-family conflict and its antecedents. Journal of Vocational Behavior, 67, 169-198. doi:10.1016/j.jvb.2004.08.009

Carlson, D.S., Kacmar, K.M., \& Williams, L.J. (2000). Construction and initial validation of a multidimensional measure of work-family conflict. Journal of Vocational Behavior, 56, 249-276. doi:10.1006/jvbe.1999.1713

Cunningham, G.B. (2008). Creating and sustaining gender diversity in sport organizations. Sex Roles, 58, 136-145. doi:10.1007/s11199-007-9312-3

Cunningham, G.B., Bruening, J., Sartore, M.L., Sagas, M., \& Fink, J.S. (2005). The application of social cognitive career theory to sport and leisure career choices. Journal of Career Development, 32, 122-138. doi:10.1177/0894845305279164

Cunningham, G.B., Doherty, A.J., \& Gregg, M.J. (2007). Using social cognitive career theory to understand head coaching intentions among assistant coaches of women's teams. Sex Roles, 56, 365-372. doi:10.1007/s11199-006-9175-z

Cunningham, G.B., Sagas, M., \& Ashley, F.B. (2003). Coaching self-efficacy, desire to become a head coach, and occupational turnover intent: Gender differences between NCAA assistant coaches of women's teams. International Journal of Sport Psychology, 34, 125-137.

DeRue, D.S., \& Wellman, N. (2009). Developing leaders via experience: The role of developmental challenge, learning orientation, and feedback availability. The Journal of Applied Psychology, 94, 859-875. PubMed doi:10.1037/a0015317

Dixon, M.A., \& Bruening, J.E. (2007). Work-family conflict in coaching I: A top-down perspective. Journal of Sport Management, 21, 377-406. doi:10.1123/jsm.21.3.377

Dixon, M.A., \& Sagas, M. (2007). The relationship between organizational support, workfamily conflict, and the job-life satisfaction of university coaches. Research Quarterly for Exercise and Sport, 78, 236-247. PubMed doi:10.1080/02701367.2007.10599421

Dragoni, L., Oh, I., Vankatwyk, P., \& Tesluk, P.E. (2011). Developing executive leaders: The relative contribution of cognitive ability, personality, and the accumulation of work experience in predicting strategic thinking competency. Personnel Psychology, 64, 829-864. doi:10.1111/j.1744-6570.2011.01229.x

Dragoni, L., Park, H., Soltis, J., \& Forte-Trammell, S. (2014). Show and tell: How supervisors facilitate leader development among transitioning leaders. The Journal of Applied Psychology, 99, 66-86. PubMed doi:10.1037/a0034452

Ehrich, L.C., Hansford, B., \& Tennent, L. (2004). Formal mentoring programs in education and other professions: A review of the literature. The Journal of Leadership for Effective and Equitable Organizations, 40, 518-540.

Ernst-Kossek, E., \& Ozeki, C. (1998). Work-family conflict, policies, and the job-life satisfaction relationship: A review and directions for organizational behavior-human resources research. The Journal of Applied Psychology, 83, 139. doi:10.1037/0021-9010.83.2.139 
Everhart, C.B., \& Chelladurai, P. (1998). Gender differences in preferences for coaching as an occupation: The role of self-efficacy, valence, and perceived barriers. Research Quarterly for Exercise and Sport, 69, 188-200. PubMed doi:10.1080/02701367.1998.10607683

Foley, S., Hang-Yue, N., \& Wong, A. (2005). Perceptions of discrimination and justice. Group \& Organization Management, 30, 421-450. doi:10.1177/1059601104265054

Ford, M.T., Heinen, B.A., \& Langkamer, K.L. (2007). Work and family satisfaction and conflict: A meta-analysis of cross-domain relations. The Journal of Applied Psychology, 92, 57-80. PubMed doi:10.1037/0021-9010.92.1.57

Gupta, V.K., Turban, D.B., \& Bhawe, N.M. (2008). The effect of gender stereotype activation on entrepreneurial intentions. The Journal of Applied Psychology, 93, 1053-1061. PubMed doi:10.1037/0021-9010.93.5.1053

Hall, J. (1976). To achieve or not: The manager's choice. California Management Review, 18, 5-18. doi:10.2307/41164664

Hannah, S., Avolio, B.J., Chan, A., \& Walumbwa, F. (2012). Leader self and means efficacy: A multi-component approach. Organizational Behavior and Human Decision Processes, 118, 143-161. doi:10.1016/j.obhdp.2012.03.007

Hannah, S.T., Avolio, B.J., Luthans, F., \& Harms, P.D. (2008). Leadership efficacy: Review and future directions. The Leadership Quarterly, 19, 669-692. doi:10.1016/j. leaqua.2008.09.007

Haynes, C.E., Wall, T.D., \& Bolden, R.I. (1999). Measures of perceived work characteristics for health services research: Test of a measurement model and normative data. Journal of Health Psychology, 4, 257-275. doi:10.1348/135910799168614

Hoobler, J.M., Wayne, S.J., \& Lemmon, G. (2009). Bosses' perceptions of family-work conflict and women's promotability: Glass ceiling effects. Academy of Management Journal, 52, 939-957. doi:10.5465/AMJ.2009.44633700

Inda, M., Rodríguez, C., \& Peña, J.V. (2013). Gender differences in applying social cognitive career theory in engineering students. Journal of Vocational Behavior, 83, 346-355. doi:10.1016/j.jvb.2013.06.010

Kelly, E.L., Moen, P., \& Tranby, E. (2011). Changing workplaces to reduce work-family conflict: Schedule control in a white-collar organization. American Sociological Review, 76, 265-290. PubMed doi:10.1177/0003122411400056

Kilty, K. (2006). Women in coaching. The Sport Psychologist, 20, 222-234. doi:10.1123/ tsp.20.2.222

Landis, R.S., Beal, D.J., \& Tesluk, P.E. (2000). A comparison of approaches to forming composite measures in structural equation models. Organizational Research Methods, 3, 186-207. doi:10.1177/109442810032003

Lent, R.W., Brown, S.D., \& Hackett, G. (1994). Toward a unifying social cognitive theory of career and academic interest, choice, and performance. Journal of Vocational Behavior, 45, 79-122. doi:10.1006/jvbe.1994.1027

Livingston, B.A., \& Judge, T.A. (2008). Emotional responses to work-family conflict: An examination of gender role orientation among working men and women. The Journal of Applied Psychology, 93, 207-216. PubMed doi:10.1037/0021-9010.93.1.207

Loder, T.L. (2005). Women administrators negotiate work-family conflicts in changing times: An intergenerational perspective. Educational Administration Quarterly, 41, 741-776. doi:10.1177/0013161X04273847

Luthans, F., Rosenkrantz, S.A., \& Hennessey, H.W. (1985). What do successful managers really do? An observation study of managerial activities. The Journal of Applied Behavioral Science, 21, 255-270. doi:10.1177/002188638502100303

McCauley, C.D., DeRue, D.S., Yost, P.R., \& Taylor, S. (2013). Experience-driven leader development: Models, tools, best practices, and advice for on-the-job development. Hoboken, NJ: John Wiley \& Sons. doi:10.1002/9781118918838

McCauley, C.D., Ohlott, P.J., \& Ruderman, M.N. (1999). Job Challenge Profile: Facilitator's guide. San Francisco: Jossey-Bass. 
Moran-Miller, K., \& Flores, L.Y. (2011). Where are the women in women's sports? Predictors of women athletes' interest in a coaching career. Research Quarterly for Exercise and Sport, 82, 109-117. PubMed doi:10.1080/02701367.2011.10599727

Morris, E., Arthur-Banning, S., \& McDowell, J. (2014). Career strategies of millennial generation female assistant coaches. Journal of Intercollegiate Sport, 7, 175-197. doi:10.1123/jis.2013-0041

Muthén, L.K., \& Muthén, B.O. (2012). Mplus (Version 7). Los Angeles: Muthén \& Muthén. [Computer software].

Landice, C. (2009). A matter of balance: Work and life in intercollegiate athletics. Retrieved from http://www.ncaa.org/sites/default/files/aMatterOfBalanceHandbook.pdf

Netemeyer, R.G., Boles, J.S., \& McMurrian, R. (1996). Development and validation of WorkFamily Conflict and Family-Work Conflict scales. The Journal of Applied Psychology, 81, 400-410. doi:10.1037/0021-9010.81.4.400

Newstrom, J.W., Monczka, R.E., \& Reif, W.E. (1974). Perceptions of the grapevine: Its value and influence. Journal of Business Communication, 11, 12-20. doi: $10.1177 / 002194367401100303$

Ng, K.Y., Ang, S., \& Chan, K.Y. (2008). Personality and leader effectiveness: A moderated mediation model of leadership self-efficacy, job demands, and job autonomy. The Journal of Applied Psychology, 93, 733-743. PubMed doi:10.1037/0021-9010.93.4.733

Podsakoff, P.M., MacKenzie, S.B., Lee, J., \& Podsakoff, N.P. (2003). Common method biases in behavioral research: A critical review of the literature and recommended remedies. The Journal of Applied Psychology, 88, 879-903. PubMed doi:10.1037/0021-9010.88.5.879

Ryan, A.M., Sacco, J.M., McFarland, L.A., \& Kriska, S.D. (2000). Applicant self-selection: Correlates of withdrawal from a multiple hurdle process. The Journal of Applied Psychology, 85, 163-179. PubMed doi:10.1037/0021-9010.85.2.163

Sagas, M., \& Cunningham, G.B. (2004). Does having "the Right Stuff” matter? Gender differences in the determinants of career success among intercollegiate athletic administrators. Sex Roles, 50, 411-421. doi:10.1023/B:SERS.0000018895.68011.fa

Sagas, M., \& Cunningham, G.B. (2005). Work and family conflict among college assistant coaches. International Journal of Sport Management, 6, 183-197.

Sanchez, J.I., \& Brock, P. (1996). Outcomes of perceived discrimination among Hispanic employees: Is diversity management a luxury or a necessity? Academy of Management Journal, 39, 704-719. doi:10.2307/256660

Sartore, M.L., \& Cunningham, G.B. (2007). Explaining the under-representation of women in leadership positions of sport organizations: A symbolic interactionist perspective. Quest, 59, 244-265. doi:10.1080/00336297.2007.10483551

Shaw, S., \& Hoeber, L. (2003). "A strong man is direct and a direct woman is a bitch": Gendered discourses and their influence on employment roles in sport organizations. Journal of Sport Management, 17, 345-375. doi:10.1123/jsm.17.4.347

Tharenou, P. (1994). How do you make it to the top? An examination of influences on women's and men's managerial advancement. Academy of Management Journal, 37, 899-931. doi:10.2307/256604

Tharenou, P. (2008). Disruptive decisions to leave home: Gender and family differences in expatriation choices. Organizational Behavior and Human Decision Processes, 105, 183-200. doi:10.1016/j.obhdp.2007.08.004

van Vianen, A.E.M., \& Keizer, W.A.J. (1996). Gender differences in managerial intention. Gender, Work and Organization, 3, 103-114. doi:10.1111/j.1468-0432.1996.tb00051.x

Whisenant, W.A. (2008). Sustaining male dominance in interscholarstic athletics: A case of homologous reproduction... or not? Sex Roles, 58, 768-775. doi:10.1007/s11199008-9397-3

Whiteside, E., \& Hardin, M. (2011). "I don't feel like I'm up against a wall of men": Negotiating difference, identity and the glass ceiling in sports information. Journal of Intercollegiate Sport, 4, 210-226. doi:10.1123/jis.4.2.210 
Wang, P., Lawler, J.J., \& Shi, K. (2010). Work-family conflict, self-efficacy, job satisfaction, and gender: Evidences from Asia. Journal of Leadership \& Organizational Studies, 17, 298-3088. doi:10.1177/1548051810368546

Won, D., Bravo, G., \& Lee, C. (2013). Careers in collegiate athletic administration: Hiring criteria and skills needed for success. Managing Leisure, 18, 71-91. doi:10.1080/13 606719.2012 .742222 